OPEN ACCESS

Edited by:

Edgar K. Selzer,

Medical University of Vienna, Austria

Reviewed by:

Liang Peng,

The First Affiliated Hospital of Sun Yat-

sen University, China

Yingming Sun,

Fujian Medical University, China

*Correspondence:

Xingchen Peng

pxx2014@163.com

Xiaolin $\mathrm{Hu}$

huxiaolin1220@126.com

${ }^{t}$ These authors have contributed equally to this work

Specialty section: This article was submitted to Head and Neck Cancer, a section of the journal

Frontiers in Oncology

Received: 30 November 2020 Accepted: 08 November 2021

Published: 29 November 2021

Citation:

Liu Z, Chen Y, Su Y, HuX and Peng $X$ (2021) Nasopharyngeal

Carcinoma: Clinical Achievements and Considerations Among

Treatment Options.

Front. Oncol. 11:635737. doi: 10.3389/fonc.2021.635737

\section{Nasopharyngeal Carcinoma: Clinical Achievements and Considerations Among Treatment Options}

\author{
Zheran $\mathrm{Liu}^{1 \dagger}$, Ye Chen ${ }^{2 \dagger}$, Yonglin Su ${ }^{1,3 \dagger}$, Xiaolin $\mathrm{Hu}^{4 *}$ and Xingchen Peng ${ }^{1 *}$ \\ ${ }^{1}$ Department of Biotherapy, Cancer Center, West China Hospital, Sichuan University, Chengdu, China, ${ }^{2}$ Department of \\ Medical Oncology, Cancer Center, the State Key Laboratory of Biotherapy, West China Hospital, West China Medical \\ School, Sichuan University, Chengdu, China, ${ }^{3}$ Department of Rehabilitation, Cancer Center, West China Hospital, Sichuan \\ University, Chengdu, China, ${ }^{4}$ Department of Nursing, West China Hospital, Sichuan University, Chengdu, China
}

Nasopharyngeal carcinoma (NPC) is a severe malignancy arising from the nasopharyngeal epithelium and is southern China's third most common cancer. With the advancement of treatment methods, early-stage NPC patients usually have a better prognosis and more prolonged survival period than those with other malignant tumors. Most treatment failures are due to distant metastasis or a locally advanced stage of NPC in the initial diagnosis. In addition, approximately $10 \%$ of patients develop local recurrence, and $10 \%-20 \%$ of patients experience distant metastasis after treatment. These patients have a poor prognosis, with a median survival of only approximately 10-15 months. In the rapid development of treatment options, the efficacy and safety of some treatments have been validated and approved for first-line treatment, while those of other treatments remain unclear. The present study aims to provide a comprehensive overview of recent advances in NPC treatment and explain the various therapeutic possibilities in treating locally advanced, recurrent, and metastatic NPC patients.

Keywords: nasopharyngeal carcinoma, intensity-modulated radiotherapy, chemotherapy, targeted therapy, immunotherapy

\section{INTRODUCTION}

Nasopharyngeal carcinoma (NPC) is a malignant tumor arising from the nasopharyngeal epithelium. Globally, there were 129,079 new cases of NPC and 72,987 deaths in 2018 (1). NPC has a unique geographical and ethnic distribution. The incidence of NPC is less than $1 / 100,000$ in Caucasians, while the prevalence of NPC is much higher in East and Southeast Asians. NPC is the third most common cancer in southern China, with an incidence of 2-10/100,000 $(2,3)$.

At present, radiotherapy (RT) is the only curative treatment for NPC. Intensity-modulated radiotherapy (IMRT) has become one of the most important achievements in the treatment of NPC. NPC usually infiltrates and grows near critical tissues and organs, including the brain stem, spinal cord, optic nerves, and optic chiasm (4). Compared with traditional two-dimensional radiotherapy (2D-RT), IMRT can deliver tumoricidal doses to the tumor while reducing the doses received by the adjacent normal tissue (5). 
However, the 5-year survival rate is only $67 \%-77 \%$ when patients receive RT alone for locoregionally advanced NPC $(6,7)$. RT combined with chemotherapy, including concurrent, adjuvant, and induction chemotherapy, has been introduced as a standard treatment. RT combined with chemotherapy can increase survival rates and decrease distant metastatic rates for locoregionally advanced NPC, while the optimal combination of treatments still needs to be defined. Furthermore, distant metastases and locoregional recurrence are still two dominant failure patterns for NPC patients $(8,9)$. Targeted therapy and immunotherapy have shown promising clinical efficacy in recurrent or metastatic NPC. The present article reviews the recent progress in the management of NPC and aims to clarify the direction of clinical research.

\section{IMRT}

Compared to traditional 2D-RT, IMRT can bring clinical benefits with less treatment-associated toxicity in NPC patients. A prospective, randomized clinical trial (RCT) recruited 616 nonmetastatic stage I to IVb (according to the American Joint Committee on Cancer [AJCC] 6th edition staging system) NPC patients to investigate the difference in the clinical outcomes and toxicities between 2D-RT and IMRT (10). The results illustrated that the IMRT group had much better 5 -year local control [hazard ratio, $(\mathrm{HR})=1.67,95 \% \mathrm{CI}=$ 1-2.77] and overall survival (OS, $\mathrm{HR}=1.77,95 \% \mathrm{CI}=1.25-2.51$ ) rates than the $2 \mathrm{D}$-RT group. In the IMRT group, the rates of acute complications (including xerostomia and oral mucositis) and late complications (including temporal lobe neuropathy, cranial nerve palsy, trismus, neck fibrosis, late xerostomia, and hearing loss) were markedly decreased (10). Zhang et al. retrospectively analyzed 7,081 nonmetastatic NPC patients, including 2,245 IMRT-treated patients and 4,838 2D-RTtreated patients. They showed that the 5-year local relapse-free survival, locoregional relapse-free survival, progression-free survival (PFS), and OS rates of IMRT-administered patients were significantly better than those of 2D-RT-administered patients (11). IMRT is also recommended for child and adolescent NPC patients. Qiu et al. demonstrated that IMRTtreated children and adolescents had a significantly higher OS, distant metastasis-free survival, and locoregional relapse-free survival than 2D-RT-treated children and adolescents. For adverse effects, no more acute toxicities occurred, while for late complications, the rate of grade 2-4 xerostomia and hearing loss were reduced in the IMRT group (12). Generally, the clinical benefits of IMRT have overwhelming superiority compared with 2D-RT. Based on the supporting evidence, for all NPC patients, IMRT with daily image guidance should be implemented according to CSCO (The Chinese Society of Clinical Oncology) and ASCO (American Society of Clinical Oncology) guidelines (13).

Can IMRT bring better local control and survival benefits than 3D-CRT? Zhang et al. conducted a meta-analysis that included eight previous studies and compared the survival outcomes of 948 IMRT-treated patients with 1,176 2DRT/3DCRT-treated patients. Treating NPC patients with IMRT was associated with a better 5-year OS (HR $=1.51,95 \% \mathrm{CI}=1.23-$ 1.87 ) and tumor local control (odds ratio $[\mathrm{OR}]=1.94,95 \% \mathrm{CI}=$ 1.53-2.46) than treating patients with $2 \mathrm{DRT} / 3 \mathrm{D}-\mathrm{CRT}$. Moreover, IMRT showed great benefits in reducing radiationinduced chronic toxicities such as trismus $(\mathrm{OR}=0.18,95 \% \mathrm{CI}=$ $0.04-0.83)$ and temporal lobe neuropathy $(\mathrm{OR}=0.44,95 \% \mathrm{CI}=$ 0.28-0.69) (14). However, this meta-analysis mixed 2D-RT and 3D-CRT into the same control group, making the comparison between IMRT and 3D-CRT alone obscure. Fang et al. suggested that there was no significant difference between the 3D-CRTand IMRT-treated groups in the 3-year locoregional control, metastasis-free survival, and OS rates ( $84.8 \%$ vs. $84.2 \%, 76.7 \%$ vs. $82.6 \%$, and $81.7 \%$ vs. $85.4 \%$, respectively, all $p>0.05$ ), but the IMRT-treated group had a better quality of life than the $3 \mathrm{D}$ CRT-treated group, especially in the acute toxicity recovery stage (15). Kuang et al. suggested that compared to 3D-CRT, IMRT provided a better 4-year locoregional tumor control rate $(93.6 \%$ vs. $85.3, p=0.012)$ and OS $(83.5 \%$ vs. $72.1 \%, p=0.036)$ with fewer side effects (16). Multi-institutional retrospective research conducted by Sung Ho Moon et al. analyzed 1,237 NPC patients and revealed that IMRT had a significantly better 5-year OS than 3D-CRT (70.7\% vs. $57.8 \%, p=0.011)(17)$. Thus, generally, using IMRT has more benefits than using $3 \mathrm{D}-\mathrm{CRT}$.

\section{PROTON THERAPY}

Although IMRT delivers therapeutic doses to tumors near critical structures in the skull, the irradiation of adjacent tissues is unavoidable because of the inherent restriction arising from the physical properties of the photon beam (18). On the other hand, proton beam therapy has shown better conformality because the properties of the Bragg peak allow maximum doses to be deposited on the target cancer. The toxicity of proton beam therapy is also less than that of IMRT because proton beam therapy can eliminate the exit dose beyond the target area (19). In 2021, a propensity score-matched study included 80 NPC patients who received intensity-modulated proton therapy (IMPT) and 278 patients who were treated with volumetric modulated arc therapy (VMAT) (20). IMPT was associated with a lower incidence of nasogastric tube placement and body weight loss because of the lower mean oral cavity dose (20). Li et al. compared the toxicity and survival outcomes of 77 patients with nonmetastatic NPC treated with IMPT or IMRT. The results showed that IMPT was associated with lower grade 2-4 acute adverse events and better oncological outcomes than IMRT, including 100\% locoregional control at 2 years (21). Given the dosimetric advantages and reduced damage to normal tissue, proton therapy may be potentially suitable for patients with recurrences who received prior radiotherapy because reirradiation with photon-based therapy might result in a high risk of complications and morbidities (22). Verma et al. systematically assessed the clinical outcomes and adverse events of patients who received proton radiotherapy for reirradiation (23). They concluded that 
irradiation using proton-based RT for head and neck cancer exhibited a good locoregional control rate and less toxicity (23). In summary, proton therapy has revealed broad therapeutic prospects and might be suitable for reirradiating patients with locoregional recurrences. More information from both prospective and retrospective studies is still warranted to provide more substantial evidence to support the role of proton therapy in the treatment of NPC patients (19).

\section{CONCURRENT CHEMORADIATION}

IMRT has been recommended as the standard treatment for stage II-IV NPC patients (24). However, IMRT alone cannot significantly reduce the distant metastasis rate, which is still the major cause of patient death (25). Distant metastasis is also the major failure pattern of NPC, especially in locoregionally advanced NPC patients (26-28). Concurrent chemoradiation therapy (CCRT) is suitable when treating locoregionally advanced NPC patients (24). The phase III Intergroup-0099 laid the status of CCRT (29). According to this trial, the 3-year PFS rate of RT alone was only $24 \%$, while for CCRT, the rate was $78 \%$, and similar results were also shown in the 3-year overall survival rate (46\% vs. $76 \%$, respectively) (29). Ribassin-Majed et al. conducted an individual patient data network meta-analysis to compare all available treatments for locally advanced NPC (30). In general, their results showed that CCRT has favorable survival outcomes compared with radiotherapy alone (30). Other RCTs further showed the advantages of CCRT over RT alone in considering PFS and overall survival (31-33). In 2018, He et al. reviewed the existing evidence and performed a comprehensive meta-analysis based on 15 randomized controlled trials comprising 1,142 patients with locoregionally advanced NPC to compare the efficiency and toxicity of using RT alone or CCRT. The results revealed that CCRT could improve the overall response rate (risk ratio, $\mathrm{RR}=0.53,95 \% \mathrm{CI}=0.43-0.66$ ) and the complete response rate $(\mathrm{RR}=0.60,95 \% \mathrm{CI}=0.51-0.71)(34)$. However, the incidence of adverse events (except grade 3-4 gastrointestinal reaction) increased, including the incidence of hematological toxicity $(p<0.0001)$, radiation-induced oral mucositis $(p=0.007)$, and radiodermatitis $(p=0.01)(34)$. In 2021 , the CSCO and ASCO guidelines recommended CCRT for all NPC patients without contraindications (13).

Since the administration of cisplatin-based CCRT may increase the adverse events of NPC patients, will newgeneration antitumor platinum-based drugs reduce the adverse effects and maintain satisfactory efficacy? Nedaplatin is a secondgeneration platinum-based chemotherapy drug and an analog of cisplatin. Nedaplatin has similar effects and is associated with fewer digestive symptoms and renal toxicity than cisplatin in the clinic. A phase II clinical trial confirmed that the regimen of induction chemotherapy with docetaxel plus nedaplatin followed by concurrent nedaplatin and IMRT is as effective as cisplatinbased induction chemotherapy and CCRT with even better tolerance and patient compliance (35). Furthermore, a phase III trial including 402 stage II-IVB (according to the AJCC 7th edition staging system) NPC patients compared the efficacy and safety of nedaplatin-based concurrent chemoradiotherapy with those of cisplatin-based concurrent chemoradiotherapy (36). The trial findings suggested that PFS and OS were comparable between these two treatment regimens, and nedaplatin-based concurrent chemoradiotherapy was associated with a lower frequency of grade 3 or 4 late auditory or hearing toxicities (36).

\section{TARGET DRUGS REPLACED CHEMOTHERAPEUTIC DRUGS IN CCRT}

EGFR-based CCRT is another emerging alternative concurrent chemotherapy regimen that may be appropriate treatment for advanced-stage NPC patients. The discussion of the comparison of treatment outcomes and toxicities of EGFR-based CCRT with cisplatin is still ongoing. At present, there are two main types of clinical drugs that can inhibit EGFR. One is monoclonal antibodies (e.g., cetuximab and nimotuzumab), and the other is small-molecule tyrosine kinase inhibitors (e.g., gefitinib). As an IgG1 monoclonal antibody, cetuximab was the first clinically verified EGFR inhibitor.

The efficacy and safety of additional anti-EGFR antibodies to standard treatment and additional concurrent anti-EGFR antibodies to radiotherapy have been evaluated by Peng et al. by literature-based meta-analyses (37). The results showed that an anti-EGFR antibody could significantly improve OS (HR = $0.51,95 \% \mathrm{CI}=0.39-0.66)$ and $\mathrm{DFS}(\mathrm{HR}=0.68,95 \% \mathrm{CI}=0.54-$ 0.86) compared to RT or chemoradiotherapy alone, but concurrent anti-EGFR antibody plus radiotherapy failed to achieve survival benefits compared with traditional cytotoxicdrug-based CCRT in locoregionally advanced NPC patients (37). For the assessment of the antitumor efficacy of the additional anti-EGFR antibody to cytotoxic regime-based CCRT, a phase II study demonstrated the clinical efficiency of treating locoregionally advanced NPC patients with concurrent cetuximab, cisplatin, and IMRT in stage III, IVa, and IVb (according to the AJCC $7^{\text {th }}$ edition staging system) NPC patients. The results demonstrated that concurrent cetuximab and cisplatin with IMRT had 86.5\% 2-year disease-free survival (DFS) in treating locoregionally advanced NPC with accepted side effects (38). Eighty-seven percent of patients showed grade 3-4 oropharyngeal mucositis, and $10 \%$ of patients had grade 3 cetuximab-related acneiform rash (38). Recently, You et al. recruited stage II-IVb (according to the AJCC 7th edition staging system) NPC patients to compare the treatment efficacy between the CCRT alone group and the CCRT plus cetuximab group. The results showed that the CCRT plus cetuximab group had better OS, DFS, and distant metastasisfree survival (39). However, in the same year, Li et al. performed a case-control study to compare the efficacy and toxicities of applying cisplatin-based CCRT alone and concomitant cetuximab for NPC patients in stage II to IVb (according to the AJCC 7th edition staging system). The result was the opposite of the conclusion of You et al. It suggested that CCRT plus cetuximab had no significant benefit in improving 
the OS, PFS, and distant metastasis-free survival of NPC patients (CCRT plus cetuximab vs. CCRT alone: $89.7 \%$ vs. $90.7 \%, 83.9 \%$ vs. $88.7 \%$, and $88.4 \%$ vs. $91.9 \%$, respectively). In addition, CCRT plus cetuximab may even aggravate acute mucositis and acneiform rash (40). In 2018, Wang et al. conducted a metaanalysis including 783 qualified patients. The results showed that both the complete response rate $(\mathrm{RR}=1.97,95 \% \mathrm{CI}=1.57-2.46)$ and the response rate $(\mathrm{RR}=1.32,95 \% \mathrm{CI}=1.20-1.46)$ of patients treated with CCRT plus cetuximab were significantly better than those of patients treated with CCRT alone, while the 3-year OS rate $(\mathrm{RR}=1.09,95 \% \mathrm{CI}=0.86-1.39)$ and side effects were not different between the two groups (41). The main toxicities were mucositis $(\mathrm{RR}=1.27,95 \% \mathrm{CI}=0.86-1.88)$ and $\operatorname{rash}(\mathrm{RR}=1.46$; $95 \% \mathrm{CI}=0.88-2.44)$. However, this study had a strong selection bias because all the patients were from China. Thus, the pros and cons of using cetuximab with CCRT still need to be further discussed.

In addition, VEGF-targeted drugs may also boost the efficacy of CCRT. Bevacizumab is a restructured humanized monoclonal VEGF-targeted antibody with positive therapeutic outcomes in multiple cancers, including colorectal cancer, lung cancer, breast cancer, and renal cancer (42-45). The application of adding bevacizumab to cisplatin and radiotherapy for stage III-IV disease could enhance the treatment effects with manageable toxicities (46). Another phase II RCT evaluated the clinical effects of adding bevacizumab to cisplatin-based CCRT. The 2year locoregional progression-free survival, distant metastasisfree survival, PFS, and OS rates were $83.7 \%, 90.8 \%, 74.7 \%$, and $90.9 \%$, respectively, and no unusual grade 3-4 toxicity events were observed (47). Thus, the results showed that bevacizumab had strong associations with a better treatment outcome when added to CCRT.

\section{ADDITIONAL ADJUVANT CHEMOTHERAPY AFTER CCRT FOR LOCOREGIONALLY ADVANCED NPC}

The role of adjuvant chemotherapy in treating locoregionally advanced NPC is ambiguous. Although the Intergroup-0099 study demonstrated an improved 3-year OS rate when applying CCRT followed by adjuvant chemotherapy, the control group used RT alone. Thus, whether the survival benefits were acquired from concurrent chemotherapy or adjuvant chemotherapy is still unclear. The efficacy of adjuvant chemotherapy is questioned in the IMRT era. Subsequent studies failed to confirm the positive influence of adjuvant chemotherapy (48-50). Chen et al. found that adjuvant cisplatin $80 \mathrm{mg} / \mathrm{m}^{2}$ and fluorouracil treatment $800 \mathrm{mg} / \mathrm{m}^{2} /$ day failed to achieve better survival by conducting a multicenter RCT. They reported no significant difference in the 5-year failure-free survival rate $(75 \%$ vs. $71 \%)$, OS $(83 \%$ vs. $80 \%)$, DFS ( $85 \%$ vs. $80 \%$ ), or locoregional failure-free survival ( $91 \%$ vs. $90 \%$ ) between additional adjuvant chemotherapy with cisplatin and fluorouracil and CCRT alone (51). In addition, a high incidence of grade 3-4 peripheral neuropathy was observed in the CCRT followed by the adjuvant chemotherapy group (2\% vs. $0.4 \%$ ) (51). Furthermore, a meta-analysis that pooled 8,036 NPC patients also demonstrated that adjuvant chemotherapy had no survival benefits in OS, PFS, distant metastasis-free survival, and locoregional recurrence-free survival (52).

Moreover, Chan et al. investigated the potential effects of adjuvant chemotherapy on plasma Epstein-Barr virus (EBV)detectable NPC patients. Patients with screened post-RT EBV DNA received an additional six cycles of cisplatin and gemcitabine. The results showed no relapse-free survival benefits in NPC patients with detectable post-IMRT seropositive EBV RNA compared with undetectable EBV DNA patients (HR $=1.09,95 \%$ $\mathrm{CI}=0.63-1.89)$ (53). The dose reduction because of the patients' intolerance to adjuvant chemotherapy after CCRT and the failure to eliminate micrometastases using a cisplatin and fluorouracil combination might be the leading causes of failure in applying adjuvant chemotherapy.

Above all, selecting the most suitable patients and identifying the most effective drug combination for adjuvant chemotherapy are the top problems. For the first problem, omics characteristics such as miRNA or radiomics signatures might be helpful to determine the most suitable patients for adjuvant chemotherapy (54). For the second problem, the efficacy of the development of chemotherapy drugs such as capecitabine and tegafur, or biotherapy drugs such as PD-1/L1, and CTL4 inhibitors need further evaluation. Findings from a recent phase III RCT suggested that additional metronomic capecitabine as an adjuvant therapy could significantly improve failure-free survival in patients with locoregionally advanced NPC compared with standard therapy (CCRT with or without induction chemotherapy, $\mathrm{HR}=0.5,95 \% \mathrm{CI}=0.32-0.79$ ) (55). These results supported that adjuvant therapy using metronomic capecitabine might have a promising future in the treatment of locoregionally advanced NPC (55).

\section{ADDITIONAL INDUCTION CHEMOTHERAPY FOLLOWED BY CCRT FOR LOCOREGIONALLY ADVANCED NPC}

Induction chemotherapy followed by sequential CCRT has shown potential benefits for patient survival, which was confirmed by a series of RCTs (Table 1). Chen et al. pooled individual patient data from four randomized trials in endemic areas involving 1,193 NPC patients to evaluate the efficiency of applying induction chemotherapy to CCRT. The data revealed that induction chemotherapy plus CCRT was superior to CCRT alone with improved PFS (HR $=0.70,95 \% \mathrm{CI}=0.56-0.86)$ and OS (HR $=0.75,95 \%$ CI $=0.57-0.99)$ (65). Updated metaanalyses also confirmed these results $(66,67)$.

$\mathrm{PF}$ (cisplatin plus 5-FU), TP (docetaxel plus cisplatin), and TPF (docetaxel, cisplatin, and fluorouracil) are available for the current regimen options for induction chemotherapy. In 2016, a phase III, multicenter, randomized controlled trial performed by Sun et al. recruited 480 stage III-IVB (except T3-4N0) untreated NPC patients and reported that a three-cycle TPF regimen 
TABLE 1 | Recently randomized controlled trials comparing the induction chemotherapy plus concurrent chemoradiotherapy with concurrent chemoradiotherapy alone in locally advanced nasopharyngeal carcinoma.

\begin{tabular}{|c|c|c|c|c|c|c|c|c|}
\hline Study & Phase & $\begin{array}{l}\text { Sample } \\
\text { size }\end{array}$ & $\begin{array}{l}\text { Induction chemotherapy regimen at } \\
\text { experimental arm }\end{array}$ & $\begin{array}{l}\text { Concurrent } \\
\text { chemotherapy } \\
\text { regimen at control } \\
\text { group }\end{array}$ & $\begin{array}{l}\text { Median PFS } \\
(95 \% \mathrm{CI})\end{array}$ & $\begin{array}{l}\text { PFS } \\
\text { HR } \\
(95 \% \\
\text { Cl) }\end{array}$ & $\begin{array}{l}\text { Median OS } \\
(95 \% \mathrm{Cl})\end{array}$ & $\begin{array}{c}\text { OS } \\
\text { HR } \\
(95 \% \\
\text { CI) }\end{array}$ \\
\hline $\begin{array}{l}\text { Hui et al. } \\
(56)\end{array}$ & $\begin{array}{l}\text { Phase } \\
\text { ॥l }\end{array}$ & 65 & $\begin{array}{l}\text { Docetaxel } 75 \mathrm{mg} / \mathrm{m}^{2} \text { on day } 1 \text { and cisplatin } \\
75 \mathrm{mg} / \mathrm{m}^{2} \text { on day } 1 \text { every } 3 \text { weeks for } 2 \text { cycles }\end{array}$ & $\begin{array}{l}\text { Cisplatin } 40 \mathrm{mg} / \mathrm{m}^{2} \\
\text { every week for } \\
8 \text { weeks }\end{array}$ & $\begin{array}{c}\text { 3-year: } 88 \% \text { vs. } \\
60 \%\end{array}$ & $\begin{array}{c}0.49 \\
(0.20- \\
1.19)\end{array}$ & $\begin{array}{c}\text { 3-year: } 94 \% \text { vs. } \\
68 \%\end{array}$ & $\begin{array}{c}0.24 \\
(0.08- \\
0.73)\end{array}$ \\
\hline $\begin{array}{l}\text { Fountzilas } \\
\text { et al. (57) }\end{array}$ & $\begin{array}{l}\text { Phase } \\
\text { II }\end{array}$ & 141 & $\begin{array}{l}\text { Cisplatin } 75 \mathrm{mg} / \mathrm{m}^{2} \text { on day } 2 \text {, epirubicin } 75 \mathrm{mg} / \mathrm{m}^{2} \\
\text { on day } 1 \text {, and paclitaxel } 175 \mathrm{mg} / \mathrm{m}^{2} \text { on day } 1 \\
\text { every } 3 \text { weeks for } 4 \text { cycles }\end{array}$ & $\begin{array}{l}\text { Cisplatin } 40 \mathrm{mg} / \mathrm{m}^{2} \\
\text { every week }\end{array}$ & $\begin{array}{c}\text { 3-year: } 65 \% \text { vs. } \\
64 \%\end{array}$ & $\begin{array}{c}1.40 \\
(0.71- \\
2.77)\end{array}$ & $\begin{array}{c}\text { 3-year: } 67 \% \text { vs. } \\
72 \%\end{array}$ & $\begin{array}{c}0.95 \\
(0.48- \\
1.89)\end{array}$ \\
\hline $\begin{array}{l}\text { Tan et al. } \\
(58)\end{array}$ & $\begin{array}{l}\text { Phase } \\
\text { II/III }\end{array}$ & 172 & $\begin{array}{l}\text { Gemcitabine } 1,000 \mathrm{mg} / \mathrm{m}^{2} \text {, carboplatin } \mathrm{AUC}=2.5 \text {, } \\
\text { paclitaxel } 70 \mathrm{mg} / \mathrm{m}^{2} \text { on day } 1 \text { and day } 8 \text { every } 3 \\
\text { weeks for } 3 \text { cycles }\end{array}$ & $\begin{array}{l}\text { Cisplatin } 40 \mathrm{mg} / \mathrm{m}^{2} \\
\text { every week for } \\
8 \text { weeks }\end{array}$ & $\begin{array}{c}\text { 3-year DFS: } 75 \% \text { vs. } \\
67 \%\end{array}$ & $\begin{array}{c}0.77 \\
(0.44- \\
1.35)\end{array}$ & $\begin{array}{l}\text { 3-year: } 94 \% \text { vs. } \\
92 \%\end{array}$ & $\begin{array}{l}1.05 \\
(0- \\
2.19)\end{array}$ \\
\hline $\begin{array}{l}\text { Li et al. } \\
\text { (59) }\end{array}$ & $\begin{array}{l}\text { Phase } \\
\text { III }\end{array}$ & 480 & $\begin{array}{l}\text { Docetaxel } 60 \mathrm{mg} / \mathrm{m}^{2} \text { on day } 1 \text {, cisplatin } 60 \mathrm{mg} / \mathrm{m}^{2} \\
\text { on day } 1 \text {, and fluorouracil } 600 \mathrm{mg} / \mathrm{m}^{2} / \text { day on days } \\
1-5 \text { every } 3 \text { weeks for } 3 \text { cycles }\end{array}$ & $\begin{array}{l}\text { Cisplatin } 100 \mathrm{mg} / \mathrm{m}^{2} \\
\text { every } 3 \text { weeks for } \\
3 \text { cycles }\end{array}$ & $\begin{array}{c}5 \text {-year FFS: } 77 \% \text { vs. } \\
66 \%\end{array}$ & $\begin{array}{c}0.67 \\
(0.48- \\
0.91)\end{array}$ & 5-year: $86 \%$ vs.77\% & $\begin{array}{c}0.65 \\
(0.43- \\
0.98)\end{array}$ \\
\hline $\begin{array}{l}\text { Yang } \\
\text { et al. (60) }\end{array}$ & $\begin{array}{l}\text { Phase } \\
\text { III }\end{array}$ & 476 & $\begin{array}{l}\text { Cisplatin } 80 \mathrm{mg} / \mathrm{m}^{2} \text { on day } 1 \text {, fluorouracil } \\
800 \mathrm{mg} / \mathrm{m}^{2} / \text { day on days } 1-5 \text { every } 3 \text { weeks for } \\
2 \text { cycles }\end{array}$ & $\begin{array}{l}\text { Cisplatin } 80 \mathrm{mg} / \mathrm{m}^{2} \\
\text { every } 3 \text { weeks for } \\
3 \text { cycles }\end{array}$ & $\begin{array}{c}5 \text {-year DFS: } 73 \% \text { vs. } \\
63 \%\end{array}$ & $\begin{array}{c}0.66 \\
(0.48- \\
0.89)\end{array}$ & $\begin{array}{c}5 \text {-year: } 81 \% \text { vs. } \\
77 \%\end{array}$ & $\begin{array}{c}0.69 \\
(0.49- \\
0.98)\end{array}$ \\
\hline $\begin{array}{l}\text { Frikha } \\
\text { et al. (61) }\end{array}$ & $\begin{array}{l}\text { Phase } \\
\text { III }\end{array}$ & 83 & $\begin{array}{l}\text { Docetaxel } 75 \mathrm{mg} / \mathrm{m}^{2} \text { on day } 1 \text {, cisplatin } 75 \mathrm{mg} / \mathrm{m}^{2} \\
\text { day } 1 \text {, and fluorouracil } 750 \mathrm{mg} / \mathrm{m} 2 / \text { day on days } \\
1-5 \text { every } 3 \text { weeks for } 3 \text { cycles }\end{array}$ & $\begin{array}{l}\text { Cisplatin } 40 \mathrm{mg} / \mathrm{m}^{2} \\
\text { every week }\end{array}$ & $\begin{array}{c}\text { 3-year: } 74 \% \text { vs. } \\
57 \%\end{array}$ & $\begin{array}{c}0.44 \\
(0.20- \\
0.97)\end{array}$ & $\begin{array}{c}\text { 3-year: } 86 \% \text { vs. } \\
69 \%\end{array}$ & $\begin{array}{c}0.40 \\
(0.15- \\
1.04)\end{array}$ \\
\hline $\begin{array}{l}\text { Hong } \\
\text { et al. (62) }\end{array}$ & $\begin{array}{l}\text { Phase } \\
\text { III }\end{array}$ & 479 & $\begin{array}{l}\text { Mitomycin } 8 \mathrm{mg} / \mathrm{m}^{2} \text {, epirubicin } 60 \mathrm{mg} / \mathrm{m}^{2} \text {, and } \\
\text { cisplatin } 60 \mathrm{mg} / \mathrm{m}^{2} \text { on day } 1 \text {, fluorouracil } \\
450 \mathrm{mg} / \mathrm{m}^{2} \text {, and leucovorin } 30 \mathrm{mg} / \mathrm{m}^{2} \text { on day } 8 \\
\text { every } 3 \text { weeks for } 3 \text { cycles }\end{array}$ & $\begin{array}{l}\text { Cisplatin } 30 \text { mg/m² } \\
\text { every week }\end{array}$ & $\begin{array}{c}5 \text {-year DFS: } 61 \% \text { vs. } \\
50 \%\end{array}$ & $\begin{array}{c}0.74 \\
(0.57- \\
0.97)\end{array}$ & $\begin{array}{c}5 \text {-year: } 72 \% \text { vs. } \\
68 \%\end{array}$ & $\begin{array}{c}0.92 \\
(0.67- \\
1.27)\end{array}$ \\
\hline $\begin{array}{l}\text { Zhang } \\
\text { et al. (63) }\end{array}$ & $\begin{array}{l}\text { Phase } \\
\text { III }\end{array}$ & 480 & $\begin{array}{l}\text { Gemcitabine } 1,000 \mathrm{mg} / \mathrm{m}^{2} \text { on days } 1 \text { and } 8 \text {, } \\
\text { cisplatin } 80 \mathrm{mg} / \mathrm{m}^{2} \text { on day } 1 \text { every } 3 \text { weeks for } \\
3 \text { cycles }\end{array}$ & $\begin{array}{l}\text { Cisplatin } 100 \mathrm{mg} / \mathrm{m}^{2} \\
\text { every week for } \\
3 \text { cycles }\end{array}$ & $\begin{array}{c}\text { 3-year RFS: } 85 \% \text { vs. } \\
77 \%\end{array}$ & $\begin{array}{c}0.51 \\
(0.34- \\
0.77)\end{array}$ & $\begin{array}{c}\text { 3-year: } 95 \% \text { vs. } \\
90 \%\end{array}$ & $\begin{array}{c}0.43 \\
(0.24- \\
0.77)\end{array}$ \\
\hline $\begin{array}{l}\text { Lee et al. } \\
(64)\end{array}$ & $\begin{array}{l}\text { Phase } \\
\text { III }\end{array}$ & 802 & $\begin{array}{l}\text { Cisplatin } 100 \mathrm{mg} / \mathrm{m}^{2} \text {, either fluorouracil } \\
1,000 \mathrm{mg} / \mathrm{m}^{2} / \text { day for } 120 \mathrm{~h} \text { or capecitabine } \\
2,000 \mathrm{mg} / \mathrm{m}^{2} / \text { day for } 14 \text { days every } 3 \text { weeks for } \\
3 \text { cycles }\end{array}$ & $\begin{array}{l}\text { Cisplatin } 100 \mathrm{mg} / \mathrm{m}^{2} \\
\text { every } 21 \text { days for } \\
2 \text { to } 3 \text { cycles }\end{array}$ & $\begin{array}{l}\text { 5-year: } 75 \% \text { vs. } \\
\text { 69\% (control group: } \\
\text { concurrent-adjuvant } \\
\text { sequence) }\end{array}$ & $\begin{array}{c}0.84 \\
(0.65- \\
1.08)\end{array}$ & $\begin{array}{l}\text { 5-year: } 82 \% \text { vs. } 77 \% \\
\text { (control group: } \\
\text { concurrent-adjuvant } \\
\text { sequence) }\end{array}$ & $\begin{array}{c}0.82 \\
(0.62- \\
1.08)\end{array}$ \\
\hline
\end{tabular}

PFS, progression-free survival; OS, overall survival; HR, hazard ratio.

followed by CCRT was an effective regimen for locoregionally advanced NPC. The results showed that this regimen significantly improved the 3 -year failure-free survival ( $80 \%$ vs. $72 \%)$, OS ( $92 \%$ vs. $86 \%$ ), and distant failure-free survival ( $90 \%$ vs. $83 \%$ ) compared with CCRT alone (68). In 2018, the same induction regimen was confirmed to improve the PFS of patients $(\mathrm{HR}=0.44,95 \% \mathrm{CI}=0.20-0.97)(61)$. Yang et al. compared the survival outcomes of PF-based CCRT with CCRT alone in locoregionally advanced NPC. The results showed that PFbased CCRT provided significantly prolonged long-term OS, DFS, and distant metastasis-free survival with no difference in grade 3-4 adverse events compared with CCRT alone (69). The survival benefits were confirmed by a meta-analysis conducted by Maïmouna et al., which showed that the addition of induction therapy to CCRT could significantly improve OS $(\mathrm{HR}=0.68$, $95 \% \mathrm{CI}=0.511-0.91)$ and PFS $(\mathrm{HR}=0.66,95 \% \mathrm{CI}=0.57-$ 0.76) (70).

Currently, cisplatin-based induction chemotherapy plus CCRT has been recommended by the National Comprehensive Cancer Network (NCCN) clinical practice guidelines for locoregionally advanced NPC (71). Lobaplatin, a thirdgeneration platinum drug, might be an alternative to cisplatinbased induction therapy. Lv et al. conducted a phase III study that evaluated the treatment efficacy between lobaplatin-based and cisplatin-based induction therapy in the treatment of locoregional advanced NPC. The results showed that lobaplatin-based induction therapy could achieve similar survival (5-year PFS: HR $=0.98,95 \% \mathrm{CI}=0.69-1.39)$ and fewer toxic effects than cisplatin-based therapy (72).

However, which regimen has the maximum efficacy for NPC patients is still controversial. A head-to-head study comparing the outcomes is still needed for comparison. He et al. performed a network meta-analysis involving seven RCTs with 1,570 patients (73). TPF was the most effective regimen for improving the OS of locoregionally advanced NPC patients $(\mathrm{HR}=0.68,95 \% \mathrm{CI}=0.42-1.1)$. However, the adverse effects of TPF were also severe. A significant increase in hematological toxicity incidence was observed. Moreover, several phase II RCTs showed that applying gemcitabine plus cisplatin as induction chemotherapy could enhance patient survival $(74,75)$. Zhang et al. performed a multicenter phase III RCT to compare the survival outcomes between gemcitabine plus cisplatin as induction chemotherapy followed by CCRT versus CCRT alone. The results showed that recurrence-free survival and overall survival in the gemcitabine plus cisplatin group were significantly improved (3-year recurrence-free survival: 
$\mathrm{HR}=0.51,95 \% \mathrm{CI}=0.34-0.77 ; 3$-year overall survival: $\mathrm{HR}=$ $0.43,95 \% \mathrm{CI}=0.24-0.77)(63)$.

\section{TARGETED THERAPY AND IMMUNOTHERAPY FOR RECURRENT AND METASTATIC NPC}

Up to $6 \%$ of NPC patients had distant metastasis at the initial diagnosis. These patients have a poor prognosis with a median survival of approximately 10-15 months (76). In addition, approximately $10 \%$ of patients will develop local recurrence after treatment, and $10 \%-20 \%$ of patients will develop distant metastasis (77-79). However, recommended treatments for recurrent and metastatic NPC patients are still lacking. Generally, the emerging treatment options for recurrent and metastatic NPC patients include chemotherapy using gemcitabine plus cisplatin, targeted therapy using EGFR or VEGFR, and immunotherapy such as immune checkpoint inhibitors (ICIs).

Zhang et al. recruited 362 recurrent or metastatic NPC patients and randomly assigned them to the gemcitabine plus cisplatin treatment group and fluorouracil plus cisplatin treatment group in a 1:1 ratio. The median PFS time in the gemcitabine plus cisplatin group was significantly prolonged compared with that in the fluorouracil plus cisplatin group (7.6 months vs. 5.6 months, HR $=0.55,95 \% \mathrm{CI}=0.44-0.68)$. The OS of $\mathrm{HR}=0.55,95 \% \mathrm{CI}=0.44-$ 0.68 was also improved $(\mathrm{HR}=0.62,95 \% \mathrm{CI}=0.45-0.84)$. Although the adverse events were similar between the two groups, those in the gemcitabine plus cisplatin group were mainly related to hematological toxicity, while the adverse events in the fluorouracil plus cisplatin group were mainly related to mucosal inflammation (80). Recently, Ma et al. evaluated the outcomes of several standard first-line chemotherapies for recurrent or metastatic NPC patients. The treatments include PF, GP, taxanes plus platinum, and triplet combination regimens (81). The results showed that the taxanes plus platinum regimen had the best long-term efficacy, followed by GP (81). In 2020, You et al. evaluated the efficacy and safety of conducting locoregional IMRT after PF chemotherapy in patients with chemotherapy-sensitive metastatic NPC. The results showed that chemotherapy followed by locoregional IMRT could significantly improve $\mathrm{OS}(\mathrm{HR}=0.42,95 \% \mathrm{CI}=0.23-0.77)$ and PFS $(\mathrm{HR}=0.36,95 \% \mathrm{CI}=0.23-0.57)$ (82). Recently, VEGFtargeted therapies have been clinically tested for NPC patients. VEGF, a promoter of angiogenesis, participates in the formation of blood vessels. Studies have proven that VEGF is overexpressed in $2 / 3$ of NPC patients, and VEGF overexpression is related to lymph node metastasis, NPC recurrence, and poor prognosis (83). Clinical trials confirmed that upregulated VEGF was related to worse survival time, anti-VEGF treatment was efficient for inhibiting tumor angiogenesis and promoting tumor cell apoptosis, and anti-VEGF treatment could even reverse resistance to chemotherapy for patients with locoregionally advanced NPC $(83,84)$.
Sunitinib is an oral small-molecule multitarget receptor tyrosine kinase (RTK) inhibitor that can inhibit VEGFR1-3. Sunitinib was approved for treating advanced renal cell carcinoma and imatinib mesylate-resistant or intolerant gastrointestinal stromal tumors (85). Hui et al. followed 13 patients with recurrent or metastatic NPC who had previously received high-dose radiation and found modest clinical activity with a high incidence of high-grade hemorrhagic events after applying sunitinib. Patients with local tumors invading the carotid sheath should be given special attention because of the risk of fatal hemorrhage (86). Another angiogenesis inhibitor, pazopanib, reported similar results. Lim et al. performed a phase II study in which they collected 33 recurrent or metastatic NPC patients with a daily dose of $800 \mathrm{mg}$ of pazopanib (87). No complete response was observed. The median OS was 10.8 months (95\% CI = 8.6-21.8 months), with 44\% 1-year OS and $13 \%$ PFS (87). Generally, pazopanib showed encouraging activity in NPC patients with an acceptable toxicity profile.

In general, VEGF-targeted therapies exhibit certain treatment responses with better survival outcomes in treating recurrent or metastatic NPC patients. However, the increased risk of hemorrhage may lead to severe consequences and thus needs to be given additional attention. The current findings still require validation, and further investigation is warranted.

ICIs are currently an emerging strategy to treat recurrent or metastatic NPC patients. Several RCTs have been conducted to examine the efficacy and safety of ICIs for recurrent or metastatic NPC patients (Table 2). The antitumor activity and adverse effects of pembrolizumab, a humanized PD-1 antibody, were assessed by the KEYNOTE-028 study (88). In the KEYNOTE028 study, 27 PD-L1-positive unresectable or metastatic NPC patients who failed prior treatments were recruited, and the results showed that the median PFS and OS for patients receiving pembrolizumab were 6.5 and 16.5 months, respectively. Grade 3-4 drug-related adverse events occurred in eight (29.6\%) patients. Pembrolizumab might be a potential option for recurrent or metastatic NPC with acceptable toxicity (88). Another phase II RCT investigated the clinical outcome of nivolumab in treating recurrent or metastatic NPC patients. The 1-year OS rate was 59\% (95\% CI $=44.3 \%-78.5 \%)$, and the 1 -year PFS rate was $19.3 \%$ (95\% CI $=10.1 \%-37.2 \%)$ (89). In 2019, Fang et al. reported the results of two single-arm phase I trials that evaluated the antitumor efficacy and adverse effects of camrelizumab. In one trial, previously treated recurrent and metastatic NPC patients were enrolled, and in another trial, treatment-naïve recurrent and metastatic NPC patients in China were included. The results of the two RCTs demonstrated that both camrelizumab monotherapy and camrelizumab with gemcitabine and cisplatin had tolerable toxicity and potential antitumor activity in treating recurrent or metastatic NPC patients (90). Since adding camrelizumab to gemcitabine and cisplatin has shown good antitumor activity, a recent phase III RCT named CAPTAIN-1st compared camrelizumab versus placebo in combination with gemcitabine and cisplatin as firstline treatment for recurrent or metastatic NPC patients. The results showed that the camrelizumab group had significantly 
TABLE 2 | Completed clinical trials evaluating PD-1 inhibitors in recurrent and/or metastatic nasopharyngeal carcinoma.

\begin{tabular}{|c|c|c|c|c|c|c|c|c|}
\hline Study & $\begin{array}{c}\text { Trial } \\
\text { identifier }\end{array}$ & Key eligibility criteria & $\begin{array}{l}\text { Sample } \\
\text { size }\end{array}$ & Dose & ORR & $\begin{array}{l}\text { Median } \\
\text { PFS } \\
(95 \% \\
\text { CI) }\end{array}$ & $\begin{array}{l}\text { Median } \\
\text { OS } \\
(95 \% \\
\text { Cl) }\end{array}$ & $\begin{array}{l}\text { Grade } \\
3 \text { or } \\
\text { higher } \\
\text { AE }\end{array}$ \\
\hline $\begin{array}{l}\text { Hsu } \\
\text { et al. } \\
\text { (88) }\end{array}$ & NCT02054806 & $\begin{array}{l}\text { Unresectable or metastatic disease; } \\
\text { failure on standard therapy before; PD- } \\
\text { L1 expression in } 1 \% \text { or more of tumor } \\
\text { cells or tumor-infiltrating lymphocytes }\end{array}$ & 27 & $\begin{array}{l}\text { Pembrolizumab } 10 \text { mg/kg every } 2 \text { weeks up to } 2 \\
\text { years }\end{array}$ & $26 \%$ & $\begin{array}{l}16.5 \\
(10.1 \text { to } \\
\text { NR) }\end{array}$ & $\begin{array}{l}6.5(3.6 \\
\text { to } 13.4)\end{array}$ & $15 / 27$ \\
\hline $\begin{array}{l}\text { Ma } \\
\text { et al. } \\
\text { (89) }\end{array}$ & NCT02339558 & $\begin{array}{l}\text { Recurrent and/or metastatic disease; } \\
\text { received at least one prior line of } \\
\text { platinum-based chemotherapy }\end{array}$ & 44 & $\begin{array}{l}\text { Nivolumab } 3 \text { mg/kg every } 2 \text { weeks on a } 4 \text {-week } \\
\text { cycle }\end{array}$ & $21 \%$ & $\begin{array}{l}2.8(1.8 \\
\text { to } 7.4)\end{array}$ & $\begin{array}{l}17.1 \\
(10.9 \text { to } \\
\text { NR) }\end{array}$ & $10 / 44$ \\
\hline $\begin{array}{l}\text { Delord } \\
\text { et al. } \\
\text { (89) }\end{array}$ & NCT02488759 & $\begin{array}{l}\text { Recurrent and/or metastatic disease; } \\
\text { received less than two prior-line of } \\
\text { systemic therapies }\end{array}$ & 24 & Nivolumab 240 mg every 2 weeks & $21 \%$ & $\begin{array}{l}2.4(1.5 \\
\text { to } \mathrm{NR})\end{array}$ & NR & $2 / 24$ \\
\hline $\begin{array}{l}\text { Fang } \\
\text { et al. } \\
\text { (90) }\end{array}$ & NCT02721589 & $\begin{array}{l}\text { Recurrent and/or metastatic disease; } \\
\text { failure at platinum-based chemotherapy }\end{array}$ & 93 & $\begin{array}{l}\text { Camrelizumab at the prespecified doses of } 1 \mathrm{mg} / \mathrm{kg} \text {, } \\
3 \mathrm{mg} / \mathrm{kg} \text {, and } 10 \mathrm{mg} / \mathrm{kg} \text {, and a bridging dose of } \\
200 \mathrm{mg} \text { per dose once every } 2 \text { weeks }\end{array}$ & $34 \%$ & $\begin{array}{l}5.6(3.3 \\
\text { to } 7.9)\end{array}$ & NR & $15 / 93$ \\
\hline $\begin{array}{l}\text { Fang } \\
\text { et al. } \\
(90)\end{array}$ & NCT03121716 & $\begin{array}{l}\text { Recurrent and/or metastatic disease; } \\
\text { previously untreated }\end{array}$ & 23 & $\begin{array}{l}\text { Camrelizumab } 200 \mathrm{mg} \text { on day } 1 \text {, gemcitabine } \\
1 \mathrm{~g} / \mathrm{m}^{2} \text { on days } 1 \text { and } 8 \text {, and cisplatin } 80 \mathrm{mg} / \mathrm{m}^{2} \\
\text { on day } 1 \text { every } 3 \text { weeks for six cycles, followed by } \\
\text { camrelizumab } 200 \mathrm{mg} \text { maintenance once every } \\
3 \text { weeks }\end{array}$ & $91 \%$ & NR & NR & $20 / 23$ \\
\hline $\begin{array}{l}\text { Wang } \\
\text { et al. } \\
(91)\end{array}$ & NCT02915432 & $\begin{array}{l}\text { Recurrent and/or metastatic disease; } \\
\text { failure at prior standard chemotherapy, } \\
\text { or disease progression within } 6 \text { months } \\
\text { after adjuvant chemotherapy or } \\
\text { chemoradiotherapy }\end{array}$ & 190 & Toripalimabis 3 mg/kg once every 2 weeks & $21 \%$ & $\begin{array}{l}1.9(1.8 \\
\text { to } 3.5)\end{array}$ & $\begin{array}{c}17.4 \\
(11.7 \text { to } \\
22.9)\end{array}$ & $27 / 190$ \\
\hline $\begin{array}{l}\text { Yang } \\
\text { et al. } \\
(92)\end{array}$ & NCT03707509 & $\begin{array}{l}\text { Recurrent and/or metastatic disease; } \\
\text { previously untreated }\end{array}$ & 134 & $\begin{array}{l}\text { Camrelizumab } 200 \mathrm{mg} \text { every } 3 \text { weeks, cisplatin } \\
80 \mathrm{mg} / \mathrm{m}^{2} \text { on day } 1 \text { of each } 21 \text { day, at most } \\
6 \text { cycles, gemcitabine } 1,000 \mathrm{mg} / \mathrm{m}^{2} \text {, day } 1 \text { and } \\
\text { day } 8 \text { of each } 21 \text { days, maximum } 6 \text { cycles }\end{array}$ & $87 \%$ & $\begin{array}{l}9.7(8.3 \\
\text { to } 11.4)\end{array}$ & NR & $\begin{array}{l}126 / \\
134\end{array}$ \\
\hline $\begin{array}{l}\text { Even } \\
\text { et al. } \\
\text { (93) }\end{array}$ & NCT02605967 & $\begin{array}{l}\text { Nonkeratinizing recurrent and/or } \\
\text { metastatic NPC, failure at platinum- } \\
\text { based chemotherapy }\end{array}$ & 82 & Spartalizumab 400 mg once every 4 weeks & $18 \%$ & $\begin{array}{l}1.9(1.8 \\
\text { to } 3.5)\end{array}$ & $\begin{array}{c}25.2 \\
(\mathrm{NR} \text { to } \\
\mathrm{NR})\end{array}$ & $37 / 87$ \\
\hline
\end{tabular}

NR, not reached; PFS, progression-free survival; OS, overall survival; AE, adverse event; ORR, overall response rate.

longer PFS than the placebo group $(\mathrm{HR}=0.54,95 \% \mathrm{CI}=0.39$ 0.76 ), showing that camrelizumab plus gemcitabine and cisplatin could become a promising standard treatment for recurrent or metastatic NPC patients (92).

Several clinical trials have focused on using immunotherapy together with CCRT or induction chemotherapy. Moreover, combined therapy using nivolumab and ipilimumab, a CTLA-4 inhibitor, is ongoing. Generally, checkpoint inhibitors show promising antitumor effects in treating recurrent and metastatic NPC. However, the use of these checkpoint inhibitors in the real world still lacks evidence.

\section{CONCLUSION}

IMRT is widely used for NPC patients, especially in the early stage. For locoregionally advanced NPC patients, the combination of chemotherapy and IMRT is recommended. CCRT could significantly improve the survival outcome of patients. Targeted drugs or second-generation platinum-based chemotherapy drugs can reduce the adverse effects compared with platinum-based CCRT. Until now, the treatment benefits of adjuvant chemotherapy have seemed obscure. The ways to screen NPC patients suitable for adjuvant chemotherapy and identify the efficacy of new chemotherapy drugs, including EGFR inhibitors or PD-1 antibodies, need further exploration. For induction chemotherapy, head-to-head comparisons of the treatment outcomes of different regimens are still lacking. Additionally, the optimal number of chemotherapy cycles needs further confirmation. Targeted therapy and immunotherapy might be the last treatment option for metastatic or recurrent NPC patients. To date, targeted therapy and immunotherapy have shown preliminary antitumor effects, and the adverse effects were acceptable. More evidence is needed to guide the next steps in the clinical application of immunotherapy.

\section{AUTHOR CONTRIBUTIONS}

All authors contributed equally in the writing of the review article. All authors contributed to the article and approved the submitted version.

\section{FUNDING}

The work was supported by the National Natural Science Foundation of China $(82172842,81803104$, and 81672386), the 
Sichuan Province Science and Technology Support Program (2021YFSY008 and 2020YFS0276), the West China Nursing Discipline Development Special Fund Project (HXHL21008), the Technology Innovation Project of Chengdu Science and Technology Bureau (2019-YF05-00459-SN), and the

\section{REFERENCES}

1. Bray F, Ferlay J, Soerjomataram I, Siegel RL, Torre LA, Jemal A, et al. Global Cancer Statistics 2018: GLOBOCAN Estimates of Incidence and Mortality Worldwide for 36 Cancers in 185 Countries Freddie. CA Cancer J Clin (2018) 68:394-424. doi: $10.3322 /$ caac. 21492

2. Xu ZJ, Zheng RS, Zhang SW, Zou XN, Chen WQ. Nasopharyngeal Carcinoma Incidence and Mortality in China in 2009. Chin J Cancer (2013) 32:453-60. doi: 10.5732/cjc.013.10118

3. Wei K-R, Zheng R-S, Zhang S-W, Liang Z-H, Li Z-M, Chen W-Q. Nasopharyngeal Carcinoma Incidence and Mortality in China, 2013. Chin J Cancer (2017) 36:90. doi: 10.1186/s40880-017-0257-9

4. Lin S, Lu JJ, Han L, Chen Q, Pan J. Sequential Chemotherapy and IntensityModulated Radiation Therapy in the Management of Locoregionally Advanced Nasopharyngeal Carcinoma: Experience of 370 Consecutive Cases. BMC Cancer (2010) 10:39. doi: 10.1186/1471-2407-10-39

5. OuYang P-Y, Shi D, Sun R, Zhu Y-J, Xiao Y, Zhang L-N, et al. Effect of Intensity-Modulated Radiotherapy Versus Two-Dimensional Conventional Radiotherapy Alone in Nasopharyngeal Carcinoma. Oncotarget (2016) 7:33408-17. doi: 10.18632/oncotarget.8573

6. Chen CY, Han F, Zhao C, Lu LX, Sun Y, Liu XF, et al. Treatment Results and Late Complications of 556 Patients With Locally Advanced Nasopharyngeal Carcinoma Treated With Radiotherapy Alone. Br J Radiol (2009) 82:452-8. doi: $10.1259 / \mathrm{bjr} / 72813246$

7. Yi JL, Gao L, Huang Xd, Li S-y, Luo J-w, Cai W-m, et al. Nasopharyngeal Carcinoma Treated by Radical Radiotherapy Alone: Ten-Year Experience of a Single Institution. Int J Radiat Oncol Biol Phys (2006) 65:161-8. doi: 10.1016/ j.ijrobp.2005.12.003

8. Sun X, Su S, Chen C, Han F, Zhao C, Xiao W, et al. Long-Term Outcomes of Intensity-Modulated Radiotherapy for 868 Patients With Nasopharyngeal Carcinoma: An Analysis of Survival and Treatment Toxicities. Radiother Oncol (2014) 110:398-403. doi: 10.1016/j.radonc.2013.10.020

9. Tsang J, Lee VHF, Kwong DLW. Novel Therapy for Nasopharyngeal Carcinoma - Where Are We. Oral Oncol (2014) 50:798-801. doi: 10.1016/ j.oraloncology.2014.01.002

10. Peng G, Wang T, Yang KY, Zhang S, Zhang T, Li Q, et al. A Prospective, Randomized Study Comparing Outcomes and Toxicities of IntensityModulated Radiotherapy vs. Conventional Two-Dimensional Radiotherapy for the Treatment of Nasopharyngeal Carcinoma. Radiother Oncol (2012) 104:286-93. doi: 10.1016/j.radonc.2012.08.013

11. Zhang MX, Li J, Shen GP, Zou X, Xu JJ, Jiang R, et al. Intensity-Modulated Radiotherapy Prolongs the Survival of Patients With Nasopharyngeal Carcinoma Compared With Conventional Two-Dimensional Radiotherapy: A 10-Year Experience With a Large Cohort and Long Follow-Up. Eur J Cancer (2015) 51:2587-95. doi: 10.1016/j.ejca.2015.08.006

12. Qiu WZ, Peng XS, Xia HQ, Huang PY, Guo X, Cao KJ. A Retrospective Study Comparing the Outcomes and Toxicities of Intensity-Modulated Radiotherapy Versus Two-Dimensional Conventional Radiotherapy for the Treatment of Children and Adolescent Nasopharyngeal Carcinoma. J Cancer Res Clin Oncol (2017) 143:1563-72. doi: 10.1007/s00432-017-2401-y

13. Chen YP, Ismaila N, Chua MLK, Colevas AD, Haddad R, Huang SH, et al. Chemotherapy in Combination With Radiotherapy for Definitive-Intent Treatment of Stage II-IVA Nasopharyngeal Carcinoma: CSCO and ASCO Guideline. J Clin Oncol (2021) 39:840-59. doi: 10.1200/JCO.20.03237

14. Zhang B, Mo Z, Du W, Wang Y, Liu L, Wei Y. Intensity-Modulated Radiation Therapy Versus 2D-RT or 3D-CRT for the Treatment of Nasopharyngeal Carcinoma: A Systematic Review and Meta-Analysis. Oral Oncol (2015) 51:1041-6. doi: 10.1016/j.oraloncology.2015.08.005
Postdoctoral Research and Development Fund and Translational Medicine Fund of West China Hospital (2020HXBH119 and CGZH19002). The funders had no role in study design, data collection and analysis, decision to publish, or preparation of the manuscript.
15. Fang FM, Chien CY, Tsai WL, Chen HC, Hsu HC, Lui CC, et al. Quality of Life and Survival Outcome for Patients With Nasopharyngeal Carcinoma Receiving Three-Dimensional Conformal Radiotherapy vs. IntensityModulated Radiotherapy-A Longitudinal Study. Int J Radiat Oncol Biol Phys (2008) 72:356-64. doi: 10.1016/j.ijrobp.2007.12.054

16. Kuang WL, Zhou Q, Shen LF. Outcomes and Prognostic Factors of Conformal Radiotherapy Versus Intensity-Modulated Radiotherapy for Nasopharyngeal Carcinoma. Clin Transl Oncol (2012) 14:783-90. doi: 10.1007/s12094-0120864-5

17. Moon SH, Cho KH, Lee CG, Keum KC, Kim YS, Wu HG, et al. IMRT vs. 2DStrahlentherapie Oder Konformaler 3D-Strahlentherapie Beim Nasopharynxkarzinom: Folgen Für Das Überleben in Einer Koreanischen Multizentrischen Retrospektiven Studie (KROG 11-06). Strahlenther und Onkol (2016) 192:377-85. doi: 10.1007/s00066-016-0959-y

18. Gomez-Millan Barrachina J, Jerez Sainz I, Perez Rozos A, Ramirez Ros JC, Toledo Serrano MD, Lupiañez Perez Y, et al. Potential Advantages of Volumetric Arc Therapy in Head and Neck Cancer. Head Neck (2015) 37:909-14. doi: 10.1002/hed.23685

19. Leeman JE, Romesser PB, Zhou Y, McBride S, Riaz N, Sherman E, et al. Proton Therapy for Head and Neck Cancer: Expanding the Therapeutic Window. Lancet Oncol (2017) 18:e254-65. doi: 10.1016/S1470-2045(17) 30179-1

20. Chou Y-CC, Fan K-HH, Lin C-YY, Hung T-MM, Huang B-SS, Chang K-PP, et al. Intensity Modulated Proton Beam Therapy Versus Volumetric Modulated Arc Therapy for Patients With Nasopharyngeal Cancer: A Propensity Score-Matched Study. Cancers (Basel) (2021) 13:3555. doi: 10.3390/cancers13143555

21. Li X, Kitpanit S, Lee A, Mah D, Sine K, Sherman EJ, et al. Toxicity Profiles and Survival Outcomes Among Patients With Nonmetastatic Nasopharyngeal Carcinoma Treated With Intensity-Modulated Proton Therapy vs IntensityModulated Radiation Therapy. JAMA Netw Open (2021) 4:e2113205. doi: 10.1001/jamanetworkopen.2021.13205

22. De Crevoisier R, Bourhis J, Domenge C, Wibault P, Koscielny S, Lusinchi A, et al. Full-Dose Reirradiation for Unresectable Head and Neck Carcinoma: Experience at the Gustave-Roussy Institute in a Series of 169 Patients. J Clin Oncol (1998) 16:3556-62. doi: 10.1200/JCO.1998.16.11.3556

23. Verma V, Rwigema JCM, Malyapa RS, Regine WF, Simone CB. Systematic Assessment of Clinical Outcomes and Toxicities of Proton Radiotherapy for Reirradiation. Radiother Oncol (2017) 125:21-30. doi: 10.1016/j. radonc.2017.08.005

24. Simo R, Robinson M, Lei M, Sibtain A, Hickey S. Nasopharyngeal Carcinoma: United Kingdom National Multidisciplinary Guidelines. J Laryngol Otol (2016) 130:S97-S103. doi: 10.1002/ejoc.200800686

25. Li A, Xiao W, Shen G, Wang L, Xu A-A, Cao Y-Q, et al. Distant Metastasis Risk and Patterns of Nasopharyngeal Carcinoma in the Era of IMRT : LongTerm Results and Benefits of Chemotherapy. Oncotarget (2015) 6:24511-21. doi: 10.18632 /oncotarget.4312

26. Mao YP, Tang LL, Chen L, Sun Y, Qi ZY, Zhou GQ, et al. Prognostic Factors and Failure Patterns in Non-Metastatic Nasopharyngeal Carcinoma After Intensity-Modulated Radiotherapy. Chin J Cancer (2016) 35:103. doi: 10.1186/ s40880-016-0167-2

27. Guo Q, Lu T, Lin S, Zong J, Chen Z, Cui X, et al. Long-Term Survival of Nasopharyngeal Carcinoma Patients With Stage II in Intensity-Modulated Radiation Therapy Era. Jpn J Clin Oncol (2016) 46:241-7. doi: 10.1093/jjco/ hyv192

28. Luo Y, Gao Y, Yang G, Lang J. Clinical Outcome and Prognostic Factors of Intensity-Modulated Radiotherapy for T4 Stage Nasopharyngeal Carcinoma. BioMed Res Int (2016) 2016:4398498. doi: 10.1155/2016/4398498 
29. Al-Sarraf M, LeBlanc M, Giri PGS, Fu KK, Cooper J, Vuong T, et al. Chemoradiotherapy Versus Radiotherapy in Patients With Advanced Nasopharyngeal Cancer: Phase III Randomized Intergroup Study 0099. J Clin Oncol (1998) 16:1310-7. doi: 10.1200/JCO.1998.16.4.1310

30. Ribassin-Majed L, Marguet S, Lee AWM, Ng WT, Ma J, Chan ATC, et al. What Is the Best Treatment of Locally Advanced Nasopharyngeal Carcinoma? An Individual Patient Data Network Meta-Analysis. J Clin Oncol (2017) 35:498-505. doi: 10.1200/JCO.2016.67.4119

31. Chan ATC, Leung SF, Ngan RKC, Teo PML, Lau WH, Kwan WH, et al. Overall Survival After Concurrent Cisplatin-Radiotherapy Compared With Radiotherapy Alone in Locoregionally Advanced Nasopharyngeal Carcinoma. J Natl Cancer Inst (2005) 97:536-9. doi: 10.1093/jnci/dji084

32. Wu X, Huang PY, Peng PJ, Lu LX, Han F, Wu SX, et al. Long-Term FollowUp of a Phase III Study Comparing Radiotherapy With or Without Weekly Oxaliplatin for Locoregionally Advanced Nasopharyngeal Carcinoma. Ann Oncol (2013) 24:2131-6. doi: 10.1093/annonc/mdt163

33. Chen Q-Y, Wen Y-F, Guo L, Liu H, Huang P-Y, Mo H-Y, et al. Concurrent Chemoradiotherapy vs Radiotherapy Alone in Stage II Nasopharyngeal Carcinoma: Phase III Randomized Trial. JNCI J Natl Cancer Inst (2011) 103:1761-70. doi: 10.1093/jnci/djr432

34. He Y, Guo T, Guan H, Wang J, Sun Y, Peng X. Concurrent Chemoradiotherapy Versus Radiotherapy Alone for Locoregionally Advanced Nasopharyngeal Carcinoma in the Era of Intensitymodulated Radiotherapy: A Meta-Analysis. Cancer Manag Res (2018) 10:1419-28. doi: 10.2147/CMAR.S160469

35. Tang C, Wu F, Wang R, Lu H, Li G, Liu M, et al. Comparison Between Nedaplatin and Cisplatin Plus Docetaxel Combined With IntensityModulated Radiotherapy for Locoregionally Advanced Nasopharyngeal Carcinoma: A Multicenter Randomized Phase II Clinical Trial. Am J Cancer Res (2016) 6:2064-75.

36. Tang LQ, Chen DP, Guo L, Mo HY, Huang Y, Guo SS, et al. Concurrent Chemoradiotherapy With Nedaplatin Versus Cisplatin in Stage II-IVB Nasopharyngeal Carcinoma: An Open-Label, Non-Inferiority, Randomised Phase 3 Trial. Lancet Oncol (2018) 19:461-73. doi: 10.1016/S1470-2045(18) 30104-9

37. Peng L, Liu ZL, Xu C, Tang LL, Liu X, Lin AH, et al. The Efficacy and Safety of Anti-Epidermal Growth Factor Receptor Monoclonal Antibodies in Nasopharyngeal Carcinoma: Literature-Based Meta-Analyses. J Cancer (2018) 9:4510-20. doi: 10.7150/jca.27611

38. Ma BBY, Kam MKM, Leung SF, Hui EP, King AD, Chan SL, et al. A Phase II Study of Concurrent Cetuximab-Cisplatin and Intensity-Modulated Radiotherapy in Locoregionally Advanced Nasopharyngeal Carcinoma. Ann Oncol (2012) 23:1287-92. doi: 10.1093/annonc/mdr401

39. You R, Hua YJ, Liu YP, Yang Q, Zhang YN, Bin L, et al. Concurrent Chemoradiotherapy With or Without Anti-EGFR-Targeted Treatment for Stage II-IVb Nasopharyngeal Carcinoma: Retrospective Analysis With a Large Cohort and Long Follow-Up. Theranostics (2017) 7:2314-24. doi: 10.7150/ thno. 19710

40. Li Y, Chen QY, Tang LQ, Liu LT, Guo SS, Guo L, et al. Concurrent Chemoradiotherapy With or Without Cetuximab for Stage II to IVb Nasopharyngeal Carcinoma: A Case-Control Study. BMC Cancer (2017) 17:1-11. doi: 10.1186/s12885-017-3552-6

41. Wang N, Wang K, Feixue S, Liu Y. Cetuximab in Combination With Chemoradiotherapy for Nasopharyngeal Carcinoma: A Meta-Analysis. Indian J Cancer (2018) 55:196-200. doi: 10.4103/ijc.IJC

42. Saltz LB, Clarke S, Díaz-Rubio E, Scheithauer W, Figer A, Wong R, et al. Bevacizumab in Combination With Oxaliplatin-Based Chemotherapy as First-Line Therapy in Metastatic Colorectal Cancer: A Randomized Phase III Study. J Clin Oncol (2008) 26:2013-9. doi: 10.1200/JCO.2007.14.9930

43. Shih T, Lindley C. Bevacizumab: An Angiogenesis Inhibitor for the Treatment of Solid Malignancies. Clin Ther (2006) 28:1179-802. doi: 10.1016/ j.clinthera.2006.11.015

44. Von Minckwitz G. Bevacizumab Added to Neoadjuvant Chemotherapy for Breast Cancer. Breast Dis (2013) 366:310-20. doi: 10.1016/j.breastdis.2013.01.002

45. Yang JC, Haworth L, Sherry RM, Hwu P, Schwartzentruber DJ, Topalian SL, et al. A Randomized Trial of Bevacizumab, an Anti-Vascular Endothelial Growth Factor Antibody, for Metastatic Renal Cancer. N Engl J Med (2003) 349:427-34. doi: 10.1056/NEJMoa021491
46. Li J, Zhao Z, Wu X, Yao J, Ma L, Ye R, et al. Bevacizumab Plus Cisplatin and Helical Tomotherapy in Treatment of Locally Advanced Nasopharyngeal Carcinoma. Onco Targets Ther (2015) 8:1315-9. doi: 10.2147/OTT.S80159

47. Lee NY, Zhang E, Pfister DG, Kim J, Garden AS, Mechalakos J, et al. Phase II Study of the Addition of Bevacizumab to Standard Chemoradiation for LocoRegionally Advanced Nasopharyngeal Carcinoma: Radiation Therapy Oncology Group (RTOG) Trial 0615 HHS Public Access. Lancet Oncol (2012) 131016:172-80. doi: 10.1016/S1470-2045(11)70303-5

48. Wee J, Tan EH, Tai BC, Wong HB, Leong SS, Tan T, et al. Randomized Trial of Radiotherapy Versus Concurrent Chemoradiotherapy Followed by Adjuvant Chemotherapy in Patients With American Joint Committee on Cancer/International Union Against Cancer Stage III and IV Nasopharyngeal Cancer of the Endemic Variety. J Clin Oncol (2005) 23:6730-8. doi: 10.1200/ JCO.2005.16.790

49. Chen Y, Sun Y, Liang SB, Zong JF, Li WF, Chen M, et al. Progress Report of a Randomized Trial Comparing Long-Term Survival and Late Toxicity of Concurrent Chemoradiotherapy With Adjuvant Chemotherapy Versus Radiotherapy Alone in Patients With Stage III to IVB Nasopharyngeal Carcinoma From Endemic Regions of Ch. Cancer (2013) 119:2230-8. doi: $10.1002 / \mathrm{cncr} .28049$

50. Lee AWM, Tung SY, Chua DTT, Ngan RKC, Chappell R, Tung R, et al. Randomized Trial of Radiotherapy Plus Concurrent-Adjuvant Chemotherapy vs Radiotherapy Alone for Regionally Advanced Nasopharyngeal Carcinoma. J Natl Cancer Inst (2010) 102:1188-98. doi: 10.1093/jnci/djq258

51. Chen L, Hu CS, Chen XZ, Hu GQ, Cheng ZB, Sun Y, et al. Adjuvant Chemotherapy in Patients With Locoregionally Advanced Nasopharyngeal Carcinoma: Long-Term Results of a Phase 3 Multicentre Randomised Controlled Trial. Eur J Cancer (2017) 75:150-8. doi: 10.1016/j.ejca. 2017.01.002

52. Zhang B, Li MM, Chen WH, Zhao JF, Chen WQ, Dong YH, et al. Association of Chemoradiotherapy Regimens and Survival Among Patients With Nasopharyngeal Carcinoma: A Systematic Review and Meta-Analysis. JAMA Netw Open (2019) 2:e1913619-e1913619. doi: 10.1001/jamanetworkopen. 2019.13619

53. Chan ATC, Hui EP, Ngan RKC, Tung SY, Cheng ACK, Ng WT, et al. Analysis of Plasma Epstein-Barr Virus DNA in Nasopharyngeal Cancer After Chemoradiation to Identify High-Risk Patients for Adjuvant Chemotherapy: A Randomized Controlled Trial. J Clin Oncol (2018) 36:3091-100. doi: 10.1200/JCO.2018.77.7847

54. Tang XR, Li YQ, Liang SB, Jiang W, Liu F, Ge WX, et al. Development and Validation of a Gene Expression-Based Signature to Predict Distant Metastasis in Locoregionally Advanced Nasopharyngeal Carcinoma: A Retrospective, Multicentre, Cohort Study. Lancet Oncol (2018) 19:382-93. doi: 10.1016/S1470-2045(18)30080-9

55. Chen YP, Liu X, Zhou Q, Yang KY, Jin F, Zhu XD, et al. Metronomic Capecitabine as Adjuvant Therapy in Locoregionally Advanced Nasopharyngeal Carcinoma: A Multicentre, Open-Label, Parallel-Group, Randomised, Controlled, Phase 3 Trial. Lancet (2021) 398:303-13. doi: 10.1016/S0140-6736(21)01123-5

56. Hui EP, Ma BB, Leung SF, King AD, Mo F, Kam MK, et al. Randomized Phase II Trial of Concurrent Cisplatin-Radiotherapy With or Without Neoadjuvant Docetaxel and Cisplatin in Advanced Nasopharyngeal Carcinoma. J Clin Oncol (2009) 27:242-9. doi: 10.1200/JCO.2008.18.1545

57. Fountzilas G, Ciuleanu E, Bobos M, Kalogera-Fountzila A, Eleftheraki AG, Karayannopoulou G, et al. Induction Chemotherapy Followed by Concomitant Radiotherapy and Weekly Cisplatin Versus the Same Concomitant Chemoradiotherapy in Patients With Nasopharyngeal Carcinoma: A Randomized Phase II Study Conducted by the Hellenic Cooperative Oncology Group (HeCOG) With Biomarker Evaluation. Ann Oncol (2012) 23:427-35. doi: 10.1093/annonc/mdr116

58. Tan T, Lim W-T, Fong K-W, Cheah S-L, Soong Y-L, Ang M-K, et al. Concurrent Chemo-Radiation With or Without Induction Gemcitabine, Carboplatin, and Paclitaxel: A Randomized, Phase 2/3 Trial in Locally Advanced Nasopharyngeal Carcinoma. Int J Radiat Oncol Biol Phys (2015) 91:952-60. doi: 10.1016/j.ijrobp.2015.01.002

59. Li W-F, Chen N-Y, Zhang N, Hu G-Q, Xie F-Y, Sun Y, et al. Concurrent Chemoradiotherapy With/Without Induction Chemotherapy in Locoregionally Advanced Nasopharyngeal Carcinoma: Long-Term Results 
of Phase 3 Randomized Controlled Trial. Int J Cancer (2019) 145:295-305. doi: 10.1002/ijc.32099

60. Yang Q, Cao S-M, Guo L, Hua Y-J, Huang P-Y, Zhang X-L, et al. Induction Chemotherapy Followed by Concurrent Chemoradiotherapy Versus Concurrent Chemoradiotherapy Alone in Locoregionally Advanced Nasopharyngeal Carcinoma: Long-Term Results of a Phase III Multicentre Randomised Controlled Trial. Eur J Cancer (2019) 119:87-96. doi: 10.1016/ j.ejca.2019.07.007

61. Frikha M, Auperin A, Tao Y, Elloumi F, Toumi N, Blanchard P, et al. A Randomized Trial of Induction Docetaxel-Cisplatin-5FU Followed by Concomitant Cisplatin-RT Versus Concomitant Cisplatin-RT in Nasopharyngeal Carcinoma (GORTEC 2006-02). Ann Oncol (2017) 29:7316. doi: 10.1093/annonc/mdx770

62. Hong RL, Hsiao CF, Ting LL, Ko JY, Wang CW, Chang JTC, et al. Final Results of a Randomized Phase III Trial of Induction Chemotherapy Followed by Concurrent Chemoradiotherapy Versus Concurrent Chemoradiotherapy Alone in Patients With Stage IVA and IVB Nasopharyngeal CarcinomaTaiwan Cooperative Oncology Group (TCOG) 1303 Study. Ann Oncol (2018) 29:1972-9. doi: 10.1093/annonc/mdy249

63. Zhang Y, Chen L, Hu GQ, Zhang N, Zhu XD, Yang KY, et al. Gemcitabine and Cisplatin Induction Chemotherapy in Nasopharyngeal Carcinoma. $N$ Engl J Med (2019) 381:1124-35. doi: 10.1056/NEJMoa1905287

64. Lee AWM, Ngan RKC, Ng W-T, Tung SY, Cheng AAC, Kwong DLW, et al. NPC-0501 Trial on the Value of Changing Chemoradiotherapy Sequence, Replacing 5-Fluorouracil With Capecitabine, and Altering Fractionation for Patients With Advanced Nasopharyngeal Carcinoma. Cancer (2020) 126:3674-88. doi: 10.1002/cncr.32972

65. Chen YP, Tang LL, Yang Q, Poh SS, Hui EP, Chan ATC, et al. Induction Chemotherapy Plus Concurrent Chemoradiotherapy in Endemic Nasopharyngeal Carcinoma: Individual Patient Data Pooled Analysis of Four Randomized Trials. Clin Cancer Res (2018) 24:1824-33. doi: 10.1158/ 1078-0432.CCR-17-2656

66. Wang B-C, Xiao B-Y, Lin G-H, Wang C, Liu Q. The Efficacy and Safety of Induction Chemotherapy Combined With Concurrent Chemoradiotherapy Versus Concurrent Chemoradiotherapy Alone in Nasopharyngeal Carcinoma Patients: A Systematic Review and Meta-Analysis. BMC Cancer (2020) 20:393. doi: 10.1186/s12885-020-06912-3

67. OuYang P, Zhang X, Qiu X, Liu Z, Lu L, Gao Y, et al. A Pairwise MetaAnalysis of Induction Chemotherapy in Nasopharyngeal Carcinoma. Oncologist (2019) 24:505-12. doi: 10.1634/theoncologist.2018-0522

68. Sun Y, Li WF, Chen NY, Zhang N, Hu GQ, Xie FY, et al. Induction Chemotherapy Plus Concurrent Chemoradiotherapy Versus Concurrent Chemoradiotherapy Alone in Locoregionally Advanced Nasopharyngeal Carcinoma: A Phase 3, Multicentre, Randomised Controlled Trial. Lancet Oncol (2016) 17:1509-20. doi: 10.1016/S1470-2045(16)30410-7

69. Chen M-Y, Yang Q, Hong M, Hong M-H. Induction Chemotherapy Followed by Concurrent Chemoradiotherapy Versus Concurrent Chemoradiotherapy Alone in Locoregionally Advanced Nasopharyngeal Carcinoma: Long-Term Results of a Phase 3 Multicenter Randomized Controlled Trial. J Clin Oncol (2019) 37:6004. doi: 10.1200/JCO.2019. 37.15_suppl.6004

70. Mané M, Benkhaled S, Dragan T, Paesmans M, Beauvois S, Lalami Y, et al. Meta-Analysis on Induction Chemotherapy in Locally Advanced Nasopharyngeal Carcinoma. Oncologist (2021) 26:e130-41. doi: 10.1002/ ONCO.13520

71. Pfister DG, Spencer S, Adelstein D, Adkins D, Anzai Y, Brizel DM, et al. Head and Neck Cancers, Version 2.2020, NCCN Clinical Practice Guidelines in Oncology. J Natl Compr Cancer Netw (2020) 18:873-98. doi: 10.6004/ jnccn.2020.0031

72. Lv X, Cao X, Xia W-X, Liu K-Y, Qiang M-Y, Guo L, et al. Induction Chemotherapy With Lobaplatin and Fluorouracil Versus Cisplatin and Fluorouracil Followed by Chemoradiotherapy in Patients With Stage IIIIVB Nasopharyngeal Carcinoma: An Open-Label, Non-Inferiority, Randomised, Controlled, Phase 3 Trial. Lancet Oncol (2021) 22:716-26. doi: 10.1016/s1470-2045(21)00075-9

73. He Y, Guo T, Wang J, Sun Y, Guan H, Wu S, et al. Which Induction Chemotherapy Regimen Followed by Cisplatin-Based Concurrent Chemoradiotherapy Is the Best Choice Among PF, TP and TPF for
Locoregionally Advanced Nasopharyngeal Carcinoma? Ann Transl Med (2019) 7:104-4. doi: 10.21037/atm.2019.02.15

74. Foo W, Ngan RKC, Law CK, Yiu HHY, Tse KC, Lau WH, et al. Combination Gemcitabine and Cisplatin Chemotherapy for Metastatic or Recurrent Nasopharyngeal Carcinoma: Report of a Phase II Study. Ann Oncol (2002) 13:1252-8. doi: 10.1093/annonc/mdf200

75. Leoncini E, Ricciardi W, Cadoni G, Arzani D, Petrelli L, Paludetti G, et al. Adult Height and Head and Neck Cancer: A Pooled Analysis Within the INHANCE Consortium. Head Neck (2014) 36:1391. doi: 10.1002/HED

76. Chen MY, Jiang R, Guo L, Zou X, Liu Q, Sun R, et al. Locoregional Radiotherapy in Patients With Distant Metastases of Nasopharyngeal Carcinoma at Diagnosis. Chin J Cancer (2013) 32:604-13. doi: 10.5732/cjc.013.10148

77. Perri F, Scarpati GDV, Caponigro F, Pisconti S, Della Vittoria Scarpati G, Caponigro F, et al. Management of Recurrent Nasopharyngeal Carcinoma: Current Perspectives. Onco Targets Ther (2019) 12:1583-91. doi: 10.2147/ OTT.S188148

78. Xu T, Tang J, Gu M, Liu L, Wei W, Yang H. Recurrent Nasopharyngeal Carcinoma: A Clinical Dilemma and Challenge. Curr Oncol (2013) 20:e40619. doi: $10.3747 /$ co.20.1456

79. Chen YP, Chan ATC, Le QT, Blanchard P, Sun Y, Ma J. Nasopharyngeal Carcinoma. Lancet (2019) 394:64-80. doi: 10.1016/S0140-6736(19)30956-0

80. Zhang L, Huang Y, Hong S, Yang Y, Yu G, Jia J, et al. Gemcitabine Plus Cisplatin Versus Fluorouracil Plus Cisplatin in Recurrent or Metastatic Nasopharyngeal Carcinoma: A Multicentre, Randomised, Open-Label, Phase 3 Trial. Lancet (2016) 388:1883-92. doi: 10.1016/S0140-6736(16)31388-5

81. Ma S, Zhou T, Huang Y, Yang Y, Zhan J, Zhang Y. The Efficacy of First-Line Chemotherapy in Recurrent or Metastatic Nasopharyngeal Carcinoma: A Systematic Review and Meta- Analysis. Ann Transl Med (2018) 6:1-13. doi: $10.21037 / \mathrm{atm} .2018 .05 .14$

82. You R, Liu Y-P, Huang P-Y, Zou X, Sun R, He Y-X, et al. Efficacy and Safety of Locoregional Radiotherapy With Chemotherapy vs Chemotherapy Alone in De Novo Metastatic Nasopharyngeal Carcinoma: A Multicenter Phase 3 Randomized Clinical Trial. JAMA Oncol (2020) 6:1345-52. doi: 10.1001/ jamaoncol.2020.1808

83. Wakisaka N, Wen QH, Yoshizaki T, Nishimura T, Furukawa M, Kawahara E, et al. Association of Vascular Endothelial Growth Factor Expression With Angiogenesis and Lymph Node Metastasis in Nasopharyngeal Carcinoma. Laryngoscope (1999) 109:810-4. doi: 10.1097/00005537-199905000-00024

84. Lee NY, Zhang Q, Pfister DG, Kim J, Garden AS, Mechalakos J, et al. Addition of Bevacizumab to Standard Chemoradiation for Locoregionally Advanced Nasopharyngeal Carcinoma (RTOG 0615): A Phase 2 Multi-Institutional Trial. Lancet Oncol (2012) 13:172-80. doi: 10.1016/S1470-2045(11)70303-5

85. Chow LQM, Eckhardt SG. Sunitinib: From Rational Design to Clinical Efficacy. J Clin Oncol (2007) 25:884-96. doi: 10.1200/JCO.2006.06.3602

86. Hui EP, Ma BBY, King AD, Mo F, Chan SL, Kam MKM, et al. Hemorrhagic Complications in a Phase II Study of Sunitinib in Patients of Nasopharyngeal Carcinoma Who Has Previously Received High-Dose Radiation. Ann Oncol (2011) 22:1280-7. doi: 10.1093/annonc/mdq629

87. Lim WT, Ng QS, Ivy P, Leong SS, Singh O, Chowbay B, et al. A Phase II Study of Pazopanib in Asian Patients With Recurrent/Metastatic Nasopharyngeal Carcinoma. Clin Cancer Res (2011) 17:5481-9. doi: 10.1158/1078-0432.CCR10-3409

88. Hsu C, Lee SH, Ejadi S, Even C, Cohen RB, Le Tourneau C, et al. Safety and Antitumor Activity of Pembrolizumab in Patients With Programmed DeathLigand 1-Positive Nasopharyngeal Carcinoma: Results of the KEYNOTE-028 Study. J Clin Oncol (2017) 35:4050-6. doi: 10.1200/JCO.2017.73.3675

89. Ma BBY, Lim WT, Goh BC, Hui EP, Lo KW, Pettinger A, et al. Antitumor Activity of Nivolumab in Recurrent and Metastatic Nasopharyngeal Carcinoma: An International, Multicenter Study of the Mayo Clinic Phase 2 Consortium (NCI9742). J Clin Oncol (2018) 36:1412-8. doi: 10.1200/JCO.2017.77.0388

90. Fang W, Yang Y, Ma Y, Hong S, Lin L, He X, et al. Camrelizumab (SHR-1210) Alone or in Combination With Gemcitabine Plus Cisplatin for Nasopharyngeal Carcinoma: Results From Two Single-Arm, Phase 1 Trials. Lancet Oncol (2018) 19:1338-50. doi: 10.1016/S1470-2045(18)30495-9

91. Wang FH, Wei XL, Feng J, Li Q, Xu N, Hu XC, et al. Efficacy, Safety, and Correlative Biomarkers of Toripalimab in Previously Treated Recurrent or Metastatic Nasopharyngeal Carcinoma: A Phase II Clinical Trial (POLARIS02). J Clin Oncol (2021) 39:704-12. doi: 10.1200/JCO.20.02712 
92. Yang Y, Qu SS, Li J, Hu C, Xu M, Li W, et al. Camrelizumab Versus Placebo in Combination With Gemcitabine and Cisplatin as First-Line Treatment for Recurrent or Metastatic Nasopharyngeal Carcinoma (CAPTAIN-1st): A Multicentre, Randomised, Double-Blind, Phase 3 Trial. Lancet Oncol (2021) 22:1162-74. doi: 10.1016/S1470-2045(21)00302-8

93. Even C, Wang H-M, Li S-H, Ngan RK-C, Dechaphunkul A, Zhang L, et al. Phase II, Randomized Study of Spartalizumab (PDR001), an Anti-PD-1 Antibody, Versus Chemotherapy in Patients With Recurrent/Metastatic Nasopharyngeal Cancer. Clin Cancer Res (2021). doi: 10.1158/1078-0432.CCR-21-0822

Conflict of Interest: The authors declare that the research was conducted in the absence of any commercial or financial relationships that could be construed as a potential conflict of interest.
Publisher's Note: All claims expressed in this article are solely those of the authors and do not necessarily represent those of their affiliated organizations, or those of the publisher, the editors and the reviewers. Any product that may be evaluated in this article, or claim that may be made by its manufacturer, is not guaranteed or endorsed by the publisher.

Copyright (c) $2021 \mathrm{Liu}, \mathrm{Chen}, \mathrm{Su}, \mathrm{Hu}$ and Peng. This is an open-access article distributed under the terms of the Creative Commons Attribution License (CC BY). The use, distribution or reproduction in other forums is permitted, provided the original author(s) and the copyright owner(s) are credited and that the original publication in this journal is cited, in accordance with accepted academic practice. No use, distribution or reproduction is permitted which does not comply with these terms. 